\title{
Nitrogen Fixation by Sulphate-reducing Bacteria
}

\author{
By MARY-ANN RIEDERER-HENDERSON* \\ AND P. W. WILSON \\ Department of Bacteriology, University of Wisconsin, \\ Madison, Wisconsin 53706, U.S.A.
}

(Accepted for publication 6 December 1969)

\begin{abstract}
SUMMARY
Nitrogen fixation has been obained with strains of Desulfovibrio vulgaris and $D$. gigas, organisms hitherto believed to be incapable of using molecular nitrogen. Fixation has been demonstrated by increases in total nitrogen and by uptake of ${ }^{15} \mathrm{~N}_{2}$. Fixation of $\mathrm{N}_{2}$ may be widespread in this genus of the sulphate-reducing bacteria.
\end{abstract}

\section{INTRODUCTION}

The research reported here was begun as a result of Postgate's comment (1965b) in a review that 'Most strains of Desulfovibrio do not fix nitrogen'. Enriched cultures from the mud of Lake Mendota, Wisconsin, not completely free of contaminating bacteria, readily fixed $\mathrm{N}_{2}$; however, the pure cultures intended as negative controls, Desulfovibrio vulgaris NCIB 8303 HILDENBOROUGH and D. gigas NCIB 9332, also fixed in some experiments. Accordingly, the attempt to purify the new isolates was discontinued in favour of a more thorough examination of this unexpected development. The results, reported briefly at the Colloquium on Nitrogen Fixation held at Sanibel Island, Florida (Silver, 1967), are given in more detail here.

\section{MATERIALS AND METHODS}

Cultures. The culture of Desulfovibrio vulgaris strain NCIB 8303 (HILDENBOROUGH) originally was obtained from Sister M. Regina Lanigan, Rosary Hill College (Buffalo, N.Y.); later, subcultures of this same strain were obtained from Professors L. L. Campbell (University of Illinois) and J. R. Postgate (University of Sussex). The purity of the cultures was routinely checked by examination in a phase microscope and inoculation of Postgate's medium A (195I). These subcultures are designated by the letters $\mathrm{R}, \mathrm{C}$ and $\mathrm{P}$ after the strain number 8303 . Crude cultures of this organism were isolated from Lake Mendota mud using the technique described by Postgate (I965a). The sources of the other cultures were: D. vulgaris NCIB 8310 (NORWAY 4) from the NCIB; D. gigas NCIB 9332 from L. L. Campbell and from H. D. Peck (University of Georgia); Desulfotomaculum nigrificans ATCC 835I from J. M. Akagi (University of Kansas).

Stock cultures were kept in screw cap test-tubes in Starkey liquid medium (1938) with $0.02 \%$ thioglycollate and $0.01 \%$ ascorbic acid added. In the nitrogen fixation U.S.A. 
studies, a modification of this medium was used containing added yeast extract and a trace element mixture prescribed by Dr Y. I. Shethna (personal communication): $\mathrm{ZnSO}_{4} .7 \mathrm{H}_{2} \mathrm{O}, \mathrm{I} \cdot \mathrm{I} ; \mathrm{MnSO}_{4} . \mathrm{H}_{2} \mathrm{O}, 0.5 ; \mathrm{CoSO}_{4}, 0.005 ; \mathrm{H}_{3} \mathrm{BO}_{3}, 0.005 ; \mathrm{Na}_{2} \mathrm{MoO}_{4}, 0.2$; $\mathrm{CuSO}_{4} \cdot 5 \mathrm{H}_{2} \mathrm{O}, 0.0007 \mathrm{mg}$. $/ 100 \mathrm{ml}$. medium. A $10 \%$ inoculum was routinely used. The Desulfovibrio species were incubated at $30^{\circ}$, the Desulfotomaculum nigrificans at $55^{\circ}$.

Analyses. Total nitrogen was estimated with a modified micro-Kjeldahl method based on colorimetric estimation of ammonia. ${ }^{15} \mathrm{~N}_{2}$ uptake was determined as follows: $20 \mathrm{ml}$. of culture in $50 \mathrm{ml}$. Erlenmeyer flasks was exposed to $0.15 \mathrm{~atm} .{ }^{15} \mathrm{~N}_{2}(33.0$ atom $\%{ }^{15} \mathrm{~N}$ ) and $0.75 \mathrm{~atm}$. helium. A partial vacuum was left in the flask to allow for production of gas. The control was an inoculated culture which was boiled or to which $2 \mathrm{ml}$. of $20 \%$ trichloroacetic acid was added. Burris \& Wilson (I957) have described details of the methods of assay.

Table I. Nitrogen fixation by Desulfovibrio species

\begin{tabular}{|c|c|c|c|c|c|}
\hline \multirow[b]{2}{*}{ Experiment } & \multirow[b]{2}{*}{ Cultures } & \multirow{2}{*}{$\begin{array}{l}\text { Days of } \\
\text { incubation }\end{array}$} & \multicolumn{3}{|c|}{ Nitrogen content in $\mu \mathrm{g} . / \mathrm{ml}$. } \\
\hline & & & Initial & Final & N. fixed \\
\hline $\mathbf{I}$ & D. vulgaris $8303 \mathrm{R}$ & 3 & $8 \cdot 8$ & $16 \cdot 9$ & $8 \cdot I$ \\
\hline 2 & & 3 & 13.5 & $26 \cdot 2$ & $12 \cdot 7$ \\
\hline \multirow[t]{3}{*}{3} & & 5 & 35.6 & $43 \cdot 8$ & $8 \cdot 2$ \\
\hline & & & 33.7 & $39 \cdot 0$ & $5 \cdot 3$ \\
\hline & & & $35 \cdot 4$ & $44^{\circ} \circ$ & $8 \cdot 6$ \\
\hline 4 & D. gigas 9332 (CAMPBELL) & 3 & II. 6 & $10 \cdot 7$ & - \\
\hline \multirow[t]{2}{*}{$\frac{4}{5}$} & & 4 & $8 \cdot 3$ & $2 \mathrm{I} \cdot 0$ & I $2 \cdot 7$ \\
\hline & & & 14.0 & $22 \cdot 4$ & 8.4 \\
\hline 6 & & 5 & $4 \mathrm{I} \cdot 2$ & $5 \mathrm{r} \cdot 0$ & $9 \cdot 8$ \\
\hline \multirow[t]{2}{*}{7} & D. desulphuricans $83 \mathrm{IO}$ & 4 & $15 \cdot 2$ & $3 \mathrm{I} \cdot 4$ & $16 \cdot 2$ \\
\hline & (NORWAY 4) & & $19 \cdot 6$ & $33 \cdot 3$ & $13 \cdot 7$ \\
\hline 8 & & 6 & $34 \cdot 6$ & $42 \cdot 8$ & $8 \cdot 2$ \\
\hline \multirow{3}{*}{$\begin{array}{r}9 \\
10\end{array}$} & D. gigas 9332 (PECK) & 5 & $23 \cdot 0$ & $26 \cdot 5$ & 3.5 \\
\hline & & 6 & 29.8 & 36.9 & $5 \cdot \mathrm{I}$ \\
\hline & & & $32 \cdot 2$ & $43 \cdot 3$ & $13 \cdot 1$ \\
\hline
\end{tabular}

Initial nitrogen in the medium supplied as yeast extract.

\section{RESULTS}

Five enrichments from Lake Mendota mud were identified as predominantly strains of Desulfovibrio vulgaris. They reduced sulphate, produced desulfoviridin, and were progressively motile vibrios. Although, in nitrogen-fixation experiments, the sulphate-reducing vibrios were the predominant organisms in these isolates, microscopic examination revealed some contaminating bacteria, confirmed by growth on the medium described by Postgate (195I). In older cultures it was sometimes difficult to detect microscopically anything but Desulfovibrio forms; however, transfer of the culture into fresh medium containing combined nitrogen encouraged growth of the contaminants.

Initially, increases in the total nitrogen as measured by the micro-Kjeldahl technique were observed with the pure cultures, but since the medium contained 20 to $40 \mu \mathrm{g}$. $\mathrm{N} / \mathrm{ml}$. as yeast extract, the gains were often small relative to the initial nitrogen (Table I). Experiments using ${ }^{15} \mathrm{~N}_{2}$ as a tracer indicated that growing cultures of Desulfovibrio 
species increased in total nitrogen (Fig. I) and incorporated ${ }^{15} \mathrm{~N}_{2}$ after several days incubation (Fig. I, Table 2).

Fixation of nitrogen by duplicate cultures varied widely and was not observed in every experiment. For example, in Expt. 12, Desulfovibrio vulgaris 8303 P was transferred from a medium containing $0 . \mathrm{I} \% \mathrm{NH}_{4} \mathrm{Cl}$ to one containing $40 \mu \mathrm{g}$. $\mathrm{N} / \mathrm{ml}$. as yeast extract; no uptake of ${ }^{15} \mathrm{~N}_{2}$ was observed. After two transfers in the yeast extract medium, the experiment was repeated and positive results were obtained. If too

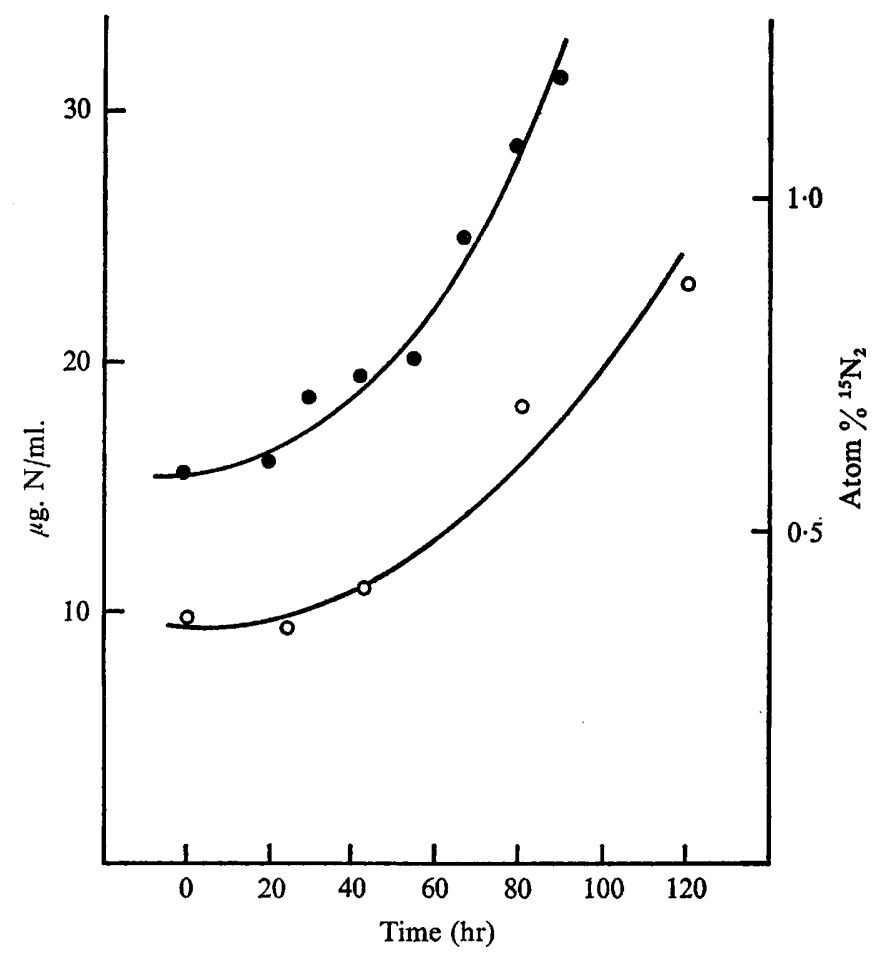

Fig. I. Time course of nitrogen fixation by Desulfovibrio vulgaris $8303 \mathrm{R}$ and D. gigas 9332 .

$\longrightarrow$ - Total nitrogen; $\mathrm{O}-\mathrm{O}$, atom $\%{ }^{15} \mathrm{~N}_{2}$.

high a concentration of yeast extract was added, however, nitrogen was not always fixed. An initial concentration of 20 to $25 \mu \mathrm{g}$. N/ml. appeared to be sufficient to start growth without preventing fixation. We suggest that the function of the added combined nitrogen is to allow the organisms to grow enough to reduce the environment sufficiently for fixation to take place. Fig. I illustrates two experiments in which the necessary conditions evidently were achieved for consistent fixation of $\mathrm{N}_{2}$. In no experiment did we obtain fixation with the thermophilic Desulfotomaculum nigrificans.

\section{DISCUSSION}

Desulfovibrio vulgaris 8303 had been examined for nitrogen fixation by Bach (1955) and several times by J. R. Postgate (personal communication), always with negative results. At our request, Professor Postgate re-examined this strain and D. gigas. 
At first the results were negative, but he has now informed us that, using a technique developed by Campbell \& Evans (1969), he has observed reproducible acetylene reduction, repressed by ammonium ions, in strains 8303 and 8310 as well as in several other Desulfovibrio strains hitherto believed to be incapable of nitrogen fixation. It thus appears that fixation of $\mathrm{N}_{2}$ is relatively widespread in this genus.

Table 2. Incorporation of ${ }^{15} N_{2}$ by cultures of sulphate-reducing bacteria

\begin{tabular}{|c|c|c|c|}
\hline Experiment & Cultures & ${ }_{15}$ Atom $\%$ & $\begin{array}{l}\mu \mathrm{g} . \mathrm{N} \\
\text { fixed } / \mathrm{ml} \text {. }\end{array}$ \\
\hline \multirow[t]{2}{*}{ II } & $\begin{array}{l}\text { Acid control } \\
\text { D. vulgaris } 8303 \mathrm{C}\end{array}$ & $\begin{array}{l}0 \cdot 370 \\
\mathrm{I} \cdot 476 \\
\mathrm{I} \cdot 675 \\
\mathrm{I} \cdot 892\end{array}$ & $\begin{array}{l}- \\
0.8 \mathrm{I} \\
0.96 \\
\mathrm{I} \cdot \mathrm{I} 2\end{array}$ \\
\hline & D. gigas 9332 & $\mathrm{r} \cdot 855$ & $1 \cdot 10$ \\
\hline \multirow[t]{2}{*}{12} & $\begin{array}{l}\text { Boiled control } \\
\text { Desulfotomaculum nigrificans } 835 \mathrm{I}\end{array}$ & $\begin{array}{l}0.376 \\
0.373 \\
0 \cdot 377\end{array}$ & - \\
\hline & D. vulgaris $8303 \mathbf{P}$ & $\begin{array}{l}0.377 \\
0.374 \\
0.380 \\
0.378\end{array}$ & - \\
\hline \multirow[t]{4}{*}{13} & $\begin{array}{l}\text { Acid control } \\
\text { D. vulgaris } 8303 \mathrm{C}\end{array}$ & $\begin{array}{l}0.470 \\
I \cdot 198\end{array}$ & $\overline{8 \cdot 80}$ \\
\hline & D. vulgaris $8303 \mathbf{P}$ & $\begin{array}{l}0.537 \\
0.748 \\
0.835 \\
0.839\end{array}$ & $\begin{array}{l}0.81 \\
3.36 \\
4.42 \\
4.46\end{array}$ \\
\hline & D. nigrificans $835 \mathrm{I}$ & $\begin{array}{l}0.378 \\
0.369\end{array}$ & - \\
\hline & D. gigas 9332 & $\begin{array}{l}2.42 \mathrm{I} \\
\mathrm{I} \cdot 846 \\
\mathrm{I} \cdot 679\end{array}$ & $\begin{array}{l}23.6 \\
16.9 \\
14.6\end{array}$ \\
\hline \multirow[t]{4}{*}{14} & $\begin{array}{l}\text { Acid control } \\
\text { D. vulgaris } 8303 \text { P }\end{array}$ & $\begin{array}{l}0 \cdot 378 \\
I \cdot 369\end{array}$ & $\overline{16 \cdot 6}$ \\
\hline & D. vulgaris $8303 \mathrm{R}$ & $\begin{array}{l}0.395 \\
0.548\end{array}$ & $\begin{array}{l}0 \cdot 3 \\
2 \cdot 8\end{array}$ \\
\hline & & 0.467 & I. 5 \\
\hline & D. vulgaris $8303 \mathrm{C}$ & $\begin{array}{l}I \cdot 572 \\
I \cdot 660\end{array}$ & $\begin{array}{l}19 \cdot 9 \\
21 \cdot 6\end{array}$ \\
\hline
\end{tabular}

Expt. I I. Medium contained $20 \mu \mathrm{g}$. $\mathrm{N} / \mathrm{ml}$. as yeast extract and cultures were incubated 5 days.

Expt. 12. Incubation time was 4 days and the medium contained $40 \mu \mathrm{g}$. N/ml. The cultures of D. vulgaris 8303 were inoculated with cells grown on $\mathrm{N}_{4}^{+} \mathrm{H}-\mathrm{N}$.

Expt. I3. The incubation time was 5 days and the medium contained $40 \mu \mathrm{g}$. N/ml.

Expt. I4. The incubation time was 4 days and the medium contained $20 \mu \mathrm{g}$. N/ml.

This research was supported in part by a National Science Foundation grant (GB-483) and by National Institutes of Health USPHS grant AI-I4I7-I4. We thank Drs J. M. Akagi, L. L. Campbell, H. D. Peck and J. R. Postgate and Sister M. Regina Lanigan for furnishing us with cultures. 


\section{REFERENCES}

BACH, M. K. (1955). Studies of nitrogen fixation by Desulfovibrio desulfuricans. M.S. Thesis, University of Wisconsin, Madison, Wis., U.S.A.

Burris, R. H. \& Wilson, P. W. (1957). Methods for measurement of nitrogen fixation. Methods in Enzymology 4, 355.

Campbell, N. E. R. \& Evans, H. J. (I969). Use of Pankhurst tubes to assay acetylene reduction by facultative and anaerobic nitrogen-fixing bacteria. Canadian Journal of Microbiology I5, I342.

Postgate, J. R. (195I). On the nutrition of Desulphovibrio desulphuricans. Journal of General Microbiology $\mathbf{5}, 7 \mathrm{I} 4$.

Postgate, J. R. (I965a). Enrichment and isolation of sulfate-reducing bacteria. In Anreicherungskultur und Mutantenauslese. Ed. by H. G. Schlegel and E. Kröger. Stuttgart: Fischer Verlag.

Postgate, J. R. (1965 b). Recent advances in the study of the sulfate-reducing bacteria. Bacteriological Reviews 29, 425.

SILVER, W. S. (1967). Biological nitrogen fixation. Science r57, Ioo.

STARKEY, R. L. (1938). A study of spore formation and other morphological characteristics of Vibrio desulfuricans. Archiv für Mikrobiologie 9, 268. 